\section{International Congress for Applied Mechanics}

THE fifth International Congress for Applied Mechanics will meet in Cambridge, Massachusetts, on September 12-16, 1938, at Harvard University and the Massachusetts Institute of Technology. The programme will cover three main divisions of applied mechanics as follows: (1) structures, elasticity, plasticity, fatigue, strength theory, crystal structure; (2) hydro- and aero-dynamies, gas dynamics, hydraulics, meteorology, water waves, heat transfer ; (3) dynamics of solids, vibration and sound, friction and Iubrication, wear and seizure. Further information can be obtained from the Secretary, Fifth International Congress for Applied Mechanics, Massachusetts Institute of Technology, Cambridge, Mass.

\section{Announcements}

Prof. G. I. TAYlor will deliver the Christmas Lectures "adapted to a juvenile auditory" at the Royal Institution, 21 Albemarle Street, London, W.1 on December 29 and 31 and January 2, 5, 7 and 9 . The subject of the lectures will be "Ships". Iurther information can be obtained from the Assistant Secretary.

THE following appointments and promotions in the Colonial Service have recently been made: Lieut.Commander J. R. de la Haule Marett, to be assistant in ethnology, Colombo Museum, Ceylon; J. A. Richardson, to be field geologist, Malaya; F. J. Ryeland, to be inspector of mines, Gold Coast ; J. R. Lockie (assistant conservator of forests, British Guiana), to be assistant conservator of forests, Nigeria; F. R. H. Green (inspector of mines, Kenya), to be superintendent of surveys, Lands and Mines Department, British Guiana ; V.T. Hockin (assistant inspector of mines), to be inspector of mines, Tanganyika; S. Napier-Bax (senior field officer), to be assistant director, Tsetse Research Department, Tanganyika; Capt. A. T. A. Ritchie (game warden, Kenya), to be chief game warden, Federated Malay States; N. H. Vicars-Harris (assistant director, Tsetse Research Department), to be secretary of the Department of Lands and Mines, Tanganyika.

AN annual sum of about $£ 30$ is available from the Clough Memorial Research Fund, which was instituted in 1935 for the purpose of encouraging geological research in Scotland and the north of England (Northumberland, Cumberland, Westmorland, Durham and Yorkshire). Applications for grants are invited for the period April 1, 1937-March 31, 1938. Further information can be obtained from the Secretary, Clough Memorial Research Fund Committee, Fdinburgh Geological Society, Synod Hall, Castle Terrace, Edinburgh.

Prof. Friedrich ZaHN, president of the Bavarian Statistical Office, has been nominated president of the International Statistical Institute.

Prof. Emil Abderhalden, director of the Physiological Institute at Halle, has been nominated an honorary member of the Sociedad Cubana de Biologia.
VIENNA has the lowest birth-rate in the world; in 1935 there were only 7 births per 1,000 inhabitants. In March 1936, there were 978 births, of which 496 were males and 482 females, while there were 2,219 deaths, of which 1,123 were males and 1,096 females, so that in a single month the population fell by 1,243 .

ERratum.-In the record of the award of the Darwin Medal of the Royal Society in NATuRE of December 5, p. 980, for Edgar James Allen, read Edgar Johnson Allen.

IN NATURE of November 28, p. 914, it should have been stated that the Rev. Wm. Tuckwell's surviving daughters are Miss Gertrude Tuckwell and Mrs. Marian Ethel Grew; Lady Weleh died three years ago.

Applicatrons are invited for the following appoint. ments, on or before the dates mentioned:

Engineer in a War Department establishment at Sutton Oak, Lancs-The Chief Superintendent, Chemical Defence Research Department, 14 Grosvenor Gardens, London, S.W.1 (December 15).

Scientific officers (chemistry), junior scientific officer (chemistry or physics), assistants (Grades I, II and III-chemistry) in the Chemical Defence Research Department-The Chief Superintendent, 14 Grosvenor Gardens, London, S.W.1 (December 15).

Mechanical engineering designer in the Design Department, Royal Arsenal, Woolwich-The UnderSecretary of State (C.5), The War Office, London, S.W.1 (Quote Appts./9) (December 15).

Assistant lecturer in civil engineering in the City and Guilds College-The Secretary, Imperial College of Science and Technology, Prince Consort Road, South Kensington, S.W.7 (December 15).

Head of the Engineering Department of the North Staffordshire Technical College-The Clerk to the Governors, Town Hall, Hanley, Stoke-on-Trent (December 16).

Assistant in the Research and Technical Publications Section of the Air Ministry - The Secretary, Air Ministry, Adastral House, Kingsway, W.C.2 (December 19).

Biochemist in the Royal Berkshire Hospital, Reading-The Secretary (December 31).

Research officer on the scientific staff of the Agricultural Research Council for work on coccidiosis-The Secretary, 6A, Dean's Yard, Westminster, S.W.1 (January 1).

Lecturer in mechanical engineering in the Derby Technical College-The Clerk to the Governors (January 4).

Physicist in the Research and Development Department of the Cambridge Instrument Co., Ltd., Cambridge.

Lecturer in pathology of the diseases of infancy and childhood in the University of GlasgowSecretary of the University Court. 